corded between $2 \mathrm{Ih}$, and $22 \mathrm{~h}$. The timings of the preliminary phases are somewhat doubtful, first, because the motions connected with them were very slight; secondly, because wind and microseismic effects masked the true earthquake effect. The following may, however, be taken as approximately correct:Primary, 2ih. $24 \mathrm{~m}$. 44s.; secondary, $2 \mathrm{rh}$. $34 \mathrm{~m}$. $4 \mathrm{~s}$. The beginning of the long-wave phase was about $2 \mathrm{Ih} .49 \mathrm{~m}$. These times correspond with an earthquake at the distance of Guatemala. The following maxima were recorded :-

\begin{tabular}{|c|c|c|}
\hline omponent & Time & Period \\
\hline E.-W. component & 2 Ih. $58 \mathrm{~m}$. I $3 \mathrm{~s}$. & $18 \mathrm{~s}$. \\
\hline
\end{tabular}

The largest vertical motions occurred about the same time. The displacements due to the horizontal waves were in the S.W.-N.E. direction. The disturbance continued until about $24 \mathrm{~h}$.

December 29, 1917.- Another large disturbance occurred on the evening of this day. Very unfortunately, the light failed about an hour before the earthqualie began, a minute particle of soot having blocked the acetylene jet. In consequence, the photographic record for the horizontal components is too faint to be read with accuracy. The vertical instrument gave a very fine record, however, and from it the following times are taken:--Primary, 23h. 2m. 43s.; secondary, $23 \mathrm{~h}$. $12 \mathrm{~m} .39 \mathrm{~s}$. The maximum displacements were at $23 \mathrm{~h}$. $37 \frac{1}{2} \mathrm{~m}$., and had a period of 2 Is. The disturbance did not die down until $\mathrm{Ih}$. 3om. on December 30 .

December 30, I9I7.-A faint disturbance was recorded from $16 \mathrm{~h}$. $4 \mathrm{Im}$. until $\mathrm{i} 7 \mathrm{~h}$. $9 \mathrm{~m}$.

January I, rgi8.-From about oh. until I5h. a somewhat unusual record was obtained from the horizontal instruments. Ordinarily, on a seismically quiet day, the trace shows nothing but the regular micro seisms. But, superposed on these, there was, during the interval referred to, an almost continual movement of an irregular kind, due most probably to a large number of minor shocks at some distant epicentre.

January 3, I9I8.-From oh. I9m. to oh. $42 \mathrm{~m}$. a faint disturbance occurred. From I4h. om. to I4h. $2 \mathrm{Im}$. a slight disturbance, including two groups of long waves, was recorded. The first group had a period averaging $26 \mathrm{~s}$., the second averaging $20 \mathrm{~s}$.

Wind effects obscured the seismogram about midnight, but the trace shows signs of faint disturbance.

January 4, I918.- A larger disturbance was noticed four hours later. The primary wave occurred at $4 \mathrm{~h}$. $44 \mathrm{~m}$. $37 \mathrm{~s}$, the secondary at $4 \mathrm{~h}$. $54 \mathrm{~m}$. $38 \mathrm{~s}$, and the long-wave phase began about $5 \mathrm{~h}$. $9 \mathrm{~m}$. These timings indicate an epicentre at the distance of Guatemala. The maximum displacement occurred at $5 \mathrm{~h}$. $19 \mathrm{~m}$. on the E.-W. instrument, its period being 20s., and the amplitude $4.2 \mu$.

At $16 \mathrm{~h} .3 \mathrm{om}$. a slight, indefinitely marked disturbance began and lasted for nearly an hour.

All the above times are G.M.T.

\section{THE PITTSBURGH MEETING OF THE AMERICAN ASSOCIATION.}

THE seventieth mieeting of the American Association for the Advancement of Science was held in Pittsburgh, Pennsylvania, December 28, r917-January 3 , I918. The total registration at the office of the permanent secretary was 692 .

The impressive keynote of the whole meeting was war preparation and efficiency. This was borne out not only in a number of symposia devoted to specific war topics, but also in other discussions, and in other papers, the titles of which would not necessarily lead one to expect a development along the line of war preparation.

$$
\text { NO. } 2522 \text {, VOL. IOO] }
$$

The opening general session of the association was held on Friday night, December 28 , in the lecture hall of the Carnegie Institution. The president of the association, Prof. T. W. Richards, of Harvard University, was absent, and Dr. G. H. Perlins, of the University of Vermont, senior vice-president, presided. Mr. H. M. Irons, city attorney of Pittsburgh, gave an address of welcome on behalf of the mayor of Pittsburgh, to which Dr. Perkins replied.

Dr. C. R. Van Hise, retiring president of the association, in his address on "Some Economic Aspects of the World War," set the note for the entire meeting. Certain special items on the programme of the week may be especially mentioned on account of their war bearing.

Section C held a symposium on "Education in Chemical Engineering."; Section $M$ held an important symposium on "Factors Concerned in an Increased Agricultural Production." Section I listened to a paper by the Hon. John Barrett on "The War and the New Pan-America," and before the same section Mr. H. E. Coffin, President of the Aircraft Board at Washington, spoke on the subject of "General Standardisation." Section B held a general interest session on the subject of "Relationship of Physics to the War." Section G, with the Botanical Society of America and the American Phytopathological Society, held a joint session on "War Problems in Botany." Dr. Vernon L. Kellogg, formerly of the Belgium Relief Commission, and now with Mr. Hoover's board in Washington, gave an exceedingly strong address before the Entomological Society of America on "The Biological Aspects of the War." Section I held a special symposium on "War Problems." Section F held a symposium on "Contributions of Zoology to Human Welfare," in which many war problems were discussed. Section $\mathrm{K}$ held a very important symposium on the subject of "Medical Problems of the War." This symposium included an address by Lieut. George Loewy, of the French Army, on "The Treatment of War Wounds by the Carrel Method," which was illustrated by moving pictures. The School Garden Association of America held a symposium on "Organisation of War Gardens." The Association of Economic Entomologists discussed the two following topics at length: "Insects and Camp Sanitation" and "How the Entomologist can Assist in Increasing Food Production." The Botanical Society of America and the American Phytopathological Society held a symposium on "Phytopathology in Relation to War Service."

It was decided to hold the next meeting of the association in Boston, Massachusetts, the meeting to begin on Friday, December 27, I918. The following officers were elected:-President, J. M. Coulter, of the University of Chicago; Presidents of Sections: A, G. D. Burkhoff, Harvard University; B, G. 'T. Hull, Dartmouth College; C, Alex. Smith, Columbia University ; D, I. N. Hollis, Worcester Polytechnic Institute; E, D. White, U.S. Geological Survey, Washington, D.C.; F, W. Patten, Dartmouth College; G, A. F. Blakeslee, Cold Spring Harbour; H, (no election); I, J. Barrett, Washington; K, F. S. Lee, Columbia University; L, S. A. Courtis. Detroit, Mich.; M, H. P. Armsbr, Pennsylvania State College.

\section{UNIVERSITY AND EDUCATIONAL INTELLIGENCE.}

Birmingham.- The council of the University and the Principal (Sir Oliver Lodge) have issued, for presentation at the annual meeting of the Court of Governors, their reports for the session rar6-i7. The war has reduced the total number of students to about $6_{3}$ per cent. of the normal. The diminution affects all facul- 